Kohl: a Journal for Body and Gender Research

Vol. 6, No. 3 (Winter 2020)

\title{
Simple Scarecrow Tense
}

\author{
e. irem az
}


*This story has won the Resisting with Fantasy Special Award at KAOS GL's 15th Women to Women Short Story Contest, in May 2020. It was originally written in Turkish and was translated to English by the author.

We are walking and not trying to name the colors of the sunset. We are only able to confirm its sheer beauty by frequently exchanging glances. An empty pool will appear on our way, all of a sudden. We start running towards the pool. We are then slowing down as we get closer, and gingerly stepping into the pool. We hadn't intended to come to a sticky end. We are here to live. At least for now, this is how we feel. We can't tell it to each other, not just yet. There is no water inside the pool. We are filling it as we swim and fuck. As we were filling it with excitement, the passersby could not see us clearly. They did not have the courage to come and disturb that which they cannot quite see.

The sun will sway in the wind, back and forth, but won't set for days. We exited the pool after an uncountable amount of time. We are leaving it to those who will find it soon after us. We were not upset, we knew how to savor it. One can avoid leaving only until death anyway. Dripping wet, we will start walking with our sore muscles. The joy of living reminds us of the mortality of our mothers. There were things both of us had to say to them before we said them to each other. I will visit the turbeh of two women before I talk to my mother. In the Byzantine times, they had been stoned to death for being in love. The regulars of their turbeh believe they are sisters. I prayed to them, and asked myself for strength. I was listening to this story in a play last night. I believe their love and the stones to be true. I will not ask Google if their bones are side by side.

After a while of walking, you suddenly stop and look into my eyes, with a careful awe. If you only knew that before I saw you, I milked generations of venom out of myself in cold blood. This is epigenetics speaking: the short life of my great aunt's six year-old-son whom she killed with a thin, rubber hose while bathing him, the fear with which my father grew up hiding underneath the couch from his devout dad's beatings, the jealousy he still feels towards the happy childhood of my mother, and so much more of the unspeakable past and present that has engendered me. This is not survival. I willfully became the scandal, the excess, and the lack. I wonder if there is anything left for you to care for. "I am so lucky and happy," you said, "how odd, how wonderful it is that you love me." I am shrinking as you speak. I was melding into you, piece by piece. For a long time, we won't notice how tenderly we meld into each other like this. I have learned not to be scared through the many days I realized the sun never rose and didn't set. I will not be scared.

The moment such lightness was about to make me cry, we start to run again. Others have joined us. We are at least five, but we cannot be sure. They may be women, they may be neither fish nor fowl, they may be all and one. As we run together, more and more we will trust each other. We were trying to get to somewhere in time, I had no idea where. I am almost breathless. My rib cage is too small. I looked at you for a second, you were also red and sweaty. The land was mostly barren around us, but I certainly saw a few green giant trees. I can smell the soil parching under the summer sun. It is overwhelming, the lemony green scent of the trees we passed by. I could still smell them too though. I will hope you can too. 
I knew whom we had been running towards this whole time the second I saw her. A dormant head under an acacia tree which resembles the one I grew up under. Her long, gray hair was dusty and linty. We will kneel down in front of her, gasping for air. We are now sitting right by her head, the only part of her body that is not buried in the soil. Her eyes had been closed for a time uncountable to us. I gently nudged her left cheek with my fingers, she didn't move. What if she doesn't open her eyes? What if we were too late? I wanted her to come to us. I will pat both her cheeks, tenderly removing a few layers of dust covering them, to wake her up.

A few more tries and she opens her eyes slightly, with a sour face. She knitted her brows. Her grim mouth bothered to cough. She will get it, she will get we finally found her, I thought to myself. I felt my eyes shining from my big quivering smile. "What the fuck are you doing," she yells at me all of a sudden, "get off my face!" I will look at you in shock, you won't seem to be surprised at all. I hear myself telling her, "we are here now, we'll dig you out. You must feel confused, just try to calm down." Her answer was a simple and frustrated "tawba astagfirullah!" I look at the others who ran with us, but they seem as unaffected by her reaction as you are. It is either that you haven't a clue about what's going on, or that you've been here before, and this time, you ran just for me. I will never know.

Still grimacing slightly, she said, "What are you doing here? Go away for the love of Allah! I wanted to be buried, I arranged it myself, and I intend to stay here!" I am now obliged to understand. "Your skinny ass can't even imagine how much this reduced my costs!" She was talking at me. I am the baffled skinny ass. I will understand eventually. Her frustration is melting away. I then saw an alarming compassion on her face. I had known it was about the future. "Darling, I'm enjoying my retirement to the fullest. Who are you to dig me out?! I'm the scarecrow, the root prostitute of this land. I'm here to remind you to live! I'd also rather not have you sap me of my remaining joy, just when I'm finally free from all the men! For goodness' sake, go live your lives and don't mess with mine!" Before I could get a grasp on myself, she had closed her eyes. Mine will open. You are here with me. The sun still hasn't set. We shall start walking again. After an uncountable amount of time, there appears another empty pool in which we won't be seen. 